\title{
The effects of rejecting aid on recipients' reputations: Evidence from natural disaster responses
}

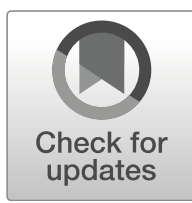

\author{
Allison Carnegie ${ }^{1} \cdot$ Lindsay R. Dolan ${ }^{2}$ \\ Published online: 30 August 2020 \\ (C) Springer Science+Business Media, LLC, part of Springer Nature 2020
}

\begin{abstract}
How do states improve their international status and prestige short of war? We argue that rejecting international assistance can boost a government's image by making it appear self-sufficient and able to provide for its citizens, leading many states to decline foreign aid. However, potential recipients only do so when they have the ability to send a credible signal and when they value status highly. We derive these hypotheses from a formal model and then use a survey experiment to demonstrate that international observers alter their opinions about potential recipients when they learn that they rejected international aid. Finally, we gather new data to empirically verify that the more resources and greater military capabilities states possess, the more likely they are to reject aid, even when they require the aid. Our results help to explain why states refuse needed assistance and suggest that many states cultivate images of self-sufficiency.
\end{abstract}

Keywords Foreign aid $\cdot$ Natural disasters $\cdot$ Signaling $\cdot$ Reputation

\section{JEL Classification F35}

A central contention in political science is that states strongly desire international status and prestige (Dafoe et al. 2014). Many scholars view the international system as a Electronic supplementary material The online version of this article
(https://doi.org/10.1007/s11558-020-09393-y) contains supplementary material, which is available to
authorized users.

$\square$ Lindsay R. Dolan

ldolan@wesleyan.edu

Allison Carnegie

allison.carnegie@columbia.edu

1 Department of Political Science, Columbia University, New York, NY, USA

2 Department of Government, Wesleyan University, Middletown, CT, USA 
hierarchy of states seeking loftier positions, and show that this goal frequently leads to inter-state conflict (Renshon 2016). States seek these attributes for their own sake, because they can provide power and influence, and because of the material benefits associated with them, such as FDI or trade concessions (Tomz 2012). But while significant attention has been given to the importance of status in international relations, we know far less about how status is determined and how states attempt to change their status. The majority of work in this area identifies war as the primary means by which states do so, but as Renshon (2016, p. 545) concludes, "it seems likely that states might use multiple strategies to alter the beliefs of their status community as to where they "stand." ${ }^{1}$ Understanding the ways in which states seek to shift other states' perceptions of their rank and power is thus crucial for moving forward the debate on how status considerations shape state behavior short of war. Comprehension of these dynamics is particularly important in the current era in which states interact more than ever in political, economic, and social domains. What strategies do these states employ to influence other states' perceptions of their strengths and capabilities?

We focus on a particular signal through which we argue that states convey increased status: self-sufficiency. While states provide assistance to other states for many reasons - including desires to stimulate economic growth and developmentwe show that such aid can also have the perverse effect of demonstrating the recipient state's weakness. While donor status confers "superiority and power" on the donor, recipient status signals "inferiority and powerlessness" (Kuusik 2006, 57). This offers an explanation for why states often reject such assistance: leaders wishing to improve their international prestige reject aid to indicate their capacity for self-sufficiency. Our findings suggest that, because highly effective governments often have little need for foreign aid, many less competent governments attempt to fool international actors into believing that they also do not require aid. Our argument comports with previous research showing that governments seek out ways to send costly signals to international audiences, often to avoid becoming stigmatized (Hyde 2011; Adler-Nissen 2014). Since it is difficult to observe a government's level of development and quality of governance, observers must rely on imperfect indicators (Heffetz and Frank 2008; Pinker et al. 2008). We claim that aid constitutes one such indicator; thus, incompetent governments that need aid may turn it down to reap the benefits associated with a better international reputation.

For example, in 2011 India's government attempted to terminate its primary source of foreign aid from Britain, as foreign minister Nirumpana Rao worried about the "negative publicity of Indian poverty promoted by [the aid]" (Gilligan 2012). ${ }^{2}$ Similarly, Pakistan's Punjab cabinet voted in favor of declining foreign aid in 2011 (Pakistan Today 2011), Kenya's President Uhuru Kenyatta encouraged African nations to shun foreign aid in 2015 (BBC News 2015), and Botswana stopped accepting much of the aid it was offered in the 1970s (Lancaster 1999, 244). For these countries, rejecting aid was a price worth paying to signal self-sufficiency.

\footnotetext{
${ }^{1}$ Status may also influence the pursuit of nuclear weapons (Levite 2003), membership in international organizations (Hafner-Burton and Montgomery 2006), and gender reforms (Towns 2010).

${ }^{2}$ Ultimately, India relented under pressure from Britain.
} 
Yet states clearly do not always decline aid offers; we argue that they do so only when international observers would find it plausible that they do not require it, and when they value status highly. ${ }^{3}$ For instance, a government that possesses considerable resources may seem to govern quite effectively. ${ }^{4}$ In such a case, international actors experience difficulty discerning whether the government is indeed self-sufficient, and rely more heavily on the rejection of aid as a signal. By contrast, a government possessing few resources and experiencing high levels of corruption and mismanagement is not likely to fool observers by refusing aid, and thus should not find it worthwhile to do so.

By formalizing and testing this argument, this article contributes both to the scholarship on status, as well as the literature on aid. The quality of governance in recipient countries is well-known to condition how effectively aid can be used to support development (Bräutigam and Knack 2004). We illustrate that political motivations influence even the decision to accept assistance. Our theory is related to, but distinct from, the literature on the "fiscal contract," which grounds the notion of state legitimacy in the relationship between tax revenue and public services (Bates and Lien 1985; Levi 1998). Scholars operating in this framework express concern that if donors rather than taxpayers visibly fund public services, citizens may lose confidence in their governments (Brass 2016; Ahmed 2012; Sacks 2012). ${ }^{5}$ Furthermore, citizens may hold governments more accountable when governments derive their budgets from tax revenues rather than aid (Paler 2013), though see De La Cuesta et al. (2017) for an alternative argument. Aid-funded projects could also entrench individuals' beliefs that government-funded projects are highly corrupt by comparison (Milner et al. 2013), though opinions of aid-funded projects may depend on whether country systems are trusted or bypassed (Knack 2013).

Rather than asking whether aid harms a government's domestic reputation, however, we ask what effect aid has on a government's international status. In particular, we examine states' attempts to change or defend their international images in order to provide a better understanding of the strategic behavior surrounding the receipt of foreign aid, along with aid's broader consequences for governments and their citizens. We do so by developing a formal model and testing its predictions in the context of humanitarian responses to natural disasters. After offering several realworld examples, we present experimental evidence that rejecting aid after a natural disaster can improve a country's international status. We then use new data to analyze cross-national variation in responses to aid offers, finding that states that value status highly — and are capable of improving their status-are more likely to reject needed aid. We also find that nearly half of the aid offers in our sample are rejected, underscoring the importance of understanding this puzzling behavior. We conclude by discussing the broader implications of our argument and possible extensions of our findings.

\footnotetext{
${ }^{3}$ While we recognize important differences in the meanings of status, reputation, and prestige (Dafoe et al. 2014), the distinctions are irrelevant to our core argument, and we use the terms interchangeably to avoid repetition.

${ }^{4}$ For links between government quality and social capital see Knack et al. (2000).

${ }^{5}$ Evidence of this relationship, however, is mixed (Bermeo 2016; Dietrich et al. 2018; Dolan et al. 2020).
} 


\section{Signaling and reputation}

We ask how states can achieve greater status within the international community short of going to war, arguing that rejecting assistance from other states represents a particularly powerful method of doing so. We develop our theory formally through a signaling model in order to derive empirical implications - which we test subsequently - and to focus attention on the key logics and causal mechanisms that drive this process. Here, we describe the game as a heuristic device and provide the full model in the Appendix of Supplementary Information (SI) due to space constraints.

The model features two primary actors: the incumbent government and the international community. The international community consists of leaders, investors, international institutions, non-governmental organizations, the mass public, and other actors. Our definition of the international community is intentionally expansive because its primary role in our model is to award status, and status is fundamentally a consensus concept. Renshon $(2016,519)$ writes, "Status is not one actor's beliefs about one other actor. Rather, status describes many actors' beliefs about what many other actors also believe." Particularly in a globalized world, a country cannot improve its status only by earning other heads of states' approval; its status will improve when these opinions are echoed in investment circles, the media, activist communities, and other networks. We leave it to others to unpack how this aggregation of beliefs occurs; for the purposes of this paper, we remain consistent with extant work in preserving a general international audience consisting of both elite and mass actors.

At the beginning of the game, a shock occurs, such as a natural disaster or an economic crisis. The incumbent chooses whether to reject or accept international assistance for help with the recovery. Incumbents come in two types: "competent" or "incompetent." Competent governments have the resources to respond adequately to the shock and do not require foreign assistance. Incompetent governments do not possess these resources, and cannot rebuild their country without foreign aid.

However, the incumbent's type is frequently unknown to the international community. A large body of scholarship illustrates the prevalence of this condition in international politics; states adopt behaviors ranging from inviting election monitors to repaying debts in order to persuade international observers of their commitments to democracy and cooperation (Gray 2013; Hyde 2011; Tomz 2012). This uncertainty is particularly pronounced when data quality is poor or where political and economic conditions change rapidly, making it difficult for observers to assess a country's situation (Jerven 2013). Further, these conditions are most likely to prevail precisely when states are most likely to seek status and take advantage of changes in the global distribution of power. Indeed, the literature characterizing war as a status-seeking strategy argues that conflict erupts most often in ambiguous circumstances, when the status a state receives is inconsistent with the status it believes it deserves (Wohlforth 2009). In other words, status-motivated behavior-military or otherwise-tends to occur in the presence of such uncertainty, so we focus on these conditions here.

Incompetent governments can thus decline foreign assistance in order to try to appear competent, though doing so comes at a price. Specifically, if the incumbent 
refuses assistance, she forgoes the aid and must expend effort concealing her inadequate response to the shock. This deception could include activities such as issuing false reports of the relief efforts' success, blocking affected citizens' abilities to communicate or organize, or making cosmetic changes to provide the illusion of recovery. Finally, if either type of state accepts aid, it pays a small cost due to the bureaucratic strain of absorbing aid and the sovereignty issues associated with accepting assistance.

The international community prefers to accord high status to competent governments and low status to incompetent governments. If they mistakenly accorded high status to an incompetent government, that government may receive undue recognition and influence at the expense of deserving countries who would perform more effectively. ${ }^{6}$ Therefore, states possess strong incentives to try to demonstrate competence to these international actors, as being held in greater esteem provides its own reward, as well as power, investment, and other benefits. However, incompetent states only do so when the expected benefits of obtaining greater status outweigh the costs of declining aid. Aid rejection not only carries the opportunity cost of losing the foregone aid but also introduces the risk that incompetent states will be caught in their attempts to seem competent. Incompetent states with fewer resources, along with those that care more about providing a speedy recovery, face steeper costs both to losing the assistance and to attempting to fool observers. After the shock occurs, the recipient decides whether to accept the aid and the international community updates its beliefs about the incumbent's type.

In equilibrium, the competent type of government always refuses assistance because, though rejecting aid entails turning down free money, accepting aid brings more risks than rewards for this type of country. In particular, the marginal benefit of aid in helping such a state respond to disasters is small and it can be difficult to coordinate the international effort. ${ }^{7}$ Incompetent types, on the other hand, are incentivized to mimic competent types by rejecting aid, but they do so only under certain conditions. First, the baseline probability that the government is competent must be high. Governments with more resources, such as middle-income governments, are more likely to be seen as competent from the outset, and thus are better able to fool the international community, whereas low-income governments are seen as too needy to trick observers. Further, the cost of pretending to be competent cannot be too great and the state cannot desire the aid too much, or the potential recipient simply cannot afford the charade. States that fall into this category again tend to possess fewer resources. Finally, states must value status highly enough to reject aid. We therefore expect the following:

\footnotetext{
${ }^{6}$ For example, a variety of programs provide benefits based on perceived merit. See, for example, the World Bank's graduation from its loans programs, membership in international groups and organizations (Davis 2016), etc. The World Bank may have misclassified Hungary, for instance, which later de-graduated (Carnegie and Samii 2019).

${ }^{7}$ For governments with the financial capacity to respond to a disaster themselves, accepting foreign aid can be comparatively more costly. Financial assistance from foreign sources is often subject to red tape and disbursement delays, while humanitarian provisions can spoil in ports. Since incumbents are often electorally punished for poor responses to natural disasters, accepting unnecessary aid entails a real political cost. See Healy and Malhotra (2009).
} 
Hypothesis 1 States that reject aid tend to experience a boost to their international reputations, unless they are caught covering up their incompetence.

Hypothesis 2 The more resources states have, the more likely they are to reject aid, even when they require the aid.

Hypothesis 3 The more states value status, the more likely they are to reject aid, even when they require the aid.

The model thus shows that aid rejection provides an avenue short of war through which states can signal competence and self-sufficiency to the international community, and thus the signal may be imitated by some states that actually need aid. Having derived testable predictions from the model, we now move to examine whether they receive empirical support.

\section{Empirical analysis}

To test the predictions of our model, we focus on a particular setting: natural disaster relief. Though our theory applies to assistance more broadly, we analyze disaster aid for several reasons. First, aid rejection following disasters represents particularly puzzling behavior due to their scale and frequency. Indeed, natural disasters often cause thousands of deaths, require billions of dollars for reconstruction, and dwarf individual countries' capacities to respond. The international community thus typically offers considerable assistance to help with rebuilding efforts. In addition to rebuilding, aid is fungible and can be used for incumbency-protection or to pursue a leader's goals more broadly (De Mesquita and Smith 2009, 2013; Bräutigam and Knack 2004; Knack 2001, 2004; Morrison 2014; Djankov et al. 2008). Yet despite the extreme need faced by victims of these disasters and the generosity of the assistance offered, governments of countries hit by these events often reject international assistance. As demonstrated in Fig. 1, out of the 66 disasters with over 300 deaths occurring between 2004 and 2012, governments rejected aid in 32 instances, which represents about half of the cases. Our study helps to answer a striking puzzle: Why would governments deny themselves the assistance they so urgently need?

This is particularly puzzling because disaster aid has few costs associated with its acceptance, unlike foreign aid given in normal times including conventional economic aid, social services aid, or aid for democracy support. In normal times, conditions are often attached to the aid, and if those conditions are enforced, they carry potential policy costs. For example, donors may require recipients to improve their human rights and democracy, ${ }^{8}$ alter economic policies, or implement a variety of other items of importance to the donor (Crawford and et al. 2001). Relatedly, donors may only be willing to fund projects that are not preferred by recipients. Such projects can carry political costs, particularly if they provide resources to the

\footnotetext{
${ }^{8}$ Though Knack (2004) finds no relationship between aid and democracy.
} 
opposition (Carothers 2006), are unpopular with the government's base of support, or use non-replaceable resources. Moreover, donors may require recipient governments to cover local costs, which are especially undesirable when the government would not undertake the project on its own (Winters and Streitfeld 2011).

A second reason to concentrate our analysis on this area is that it is useful for empirical reasons. In particular, while examining the universe of natural disasters does not eliminate problems of endogeneity, it mitigates them because the timing of these events is essentially random. ${ }^{9}$ Thus, the precise moment that a disaster hits is not determined by strategic considerations related to reputation or aid provision. The suddenness of the disaster and the urgent requirements that follow also mean that disaster aid is rarely conditioned on a country's past performance and comes with relatively few political strings attached to it. ${ }^{10}$

Third, the receipt of aid following natural disasters is typically well-publicized, as severe disasters receive extensive international coverage due to their high salience. Indeed, our case studies demonstrate that international actors pay close attention to this form of aid. Further, because disasters fall out of the news cycle quickly, after which international interest wanes, short-term responses to disasters influence a state's international status disproportionately. Immediate displays of self-sufficiency thus matter more than a steady long-term recovery plan in earning international approval, offering a government an attractive opportunity to earn improvements in status by changing its short-term behavior (Djerf-Pierre 2013; Eisensee and Strömberg 2007).

Fourth, the political economy of disaster relief represents an interesting and important topic in its own right. A burgeoning literature has shown that leaders prioritize relief for politically valuable constituencies and in areas where their actions are most visible (Healy and Malhotra 2009; Besley and Burgess 2002; Cole et al. 2012). Similarly, disasters that appear in the news are more likely to receive relief (Eisensee and Strömberg 2007). Like politicians, rebel groups can also attract supporters by delivering relief to civilians; thus, governments threatened by insurgencies should be especially inclined to provide sufficient relief themselves (Beardsley and McQuinn 2009). Scholars of international relations have also recognized the importance of natural disasters, but these works have typically focused on their diplomatic implications for conflict and cooperation between affected states and those offering assistance (Kelman 2011; Akcinaroglu et al. 2011). In contrast, our project explores the implications for an affected country's international status based on its decision to categorically accept or decline international assistance. While the disaster diplomacy literature explains why states may reject assistance from enemies, scant attention has been paid to the categorical rejection of assistance that we observe and its implications for a country's status. ${ }^{11}$

\footnotetext{
${ }^{9}$ Natural disaster severity cannot generally be considered exogenous, since countries with poorer infrastructure experience more severe disasters. Some measures of severity may be able to be considered as such, however the variation in our exogenous measure of severity is so small (see the Richter scale measure in the SI) that we focus on the exogeneity of the timing.

${ }^{10}$ While the disaster's severity is not random; we explain how we deal with this subsequently.

${ }^{11}$ Though see Nelson (2010).
} 
We test our theoretical predictions in the natural disaster setting in multiple ways. We start by illustrating our argument through examples of two countries that experienced similar exigencies but responded differently to offers of assistance, which clarify our argument and make our theory more concrete. We then turn to systematic tests of our predictions, using both a survey experiment and cross-national analysis. The survey experiment tests our hypothesis that rejecting aid can improve a country's international status. We then use our original data set of natural disaster responses to examine whether governments anticipate these status gains and seek them strategically when they are capable of convincing international audiences and when they desire status (hypotheses 2 and 3 respectively), finding support for our predictions.

\subsection{Examples}

To illustrate the model's implications, consider the difference in responses to natural disasters by two governments in the same region that have experienced similar exigencies: Sri Lanka and India. Sri Lanka, which possesses far fewer resources than India, has responded to disasters by accepting aid, while India has declined aid to signal its global power status. While Sri Lanka and India differ in many ways and thus the variation in their responses cannot be attributed solely to the factors we identify, we present these examples for illustrative purposes and conduct a more rigorous empirical examination subsequently.

\subsubsection{Sri Lanka}

Sri Lanka tends to accept aid after disasters because it possesses such inadequate resources that it cannot convince the international community of its self-sufficiency by rejecting aid. For example, Sri Lanka lacked sufficient resources to respond to the 2004 earthquake and following tsunamis, which killed 31,000 people, left 4,000 missing, and destroyed 100,000 homes in the country. The government lacked a coordinated plan for addressing such a large disaster, a tsunami warning system, or even basic disaster plans. Instead, the country faced inaccessible roads, confused rescue efforts, and an unprepared health care system, leading to fears of disease outbreaks (Yamada et al. 2006). ${ }^{12}$

Sri Lanka immediately requested aid, and received a total of $\$ 651.6$ million in assistance, including \$25 million in aid from India, itself hit hard by the tsunami (The Guardian 2014; Hall 2004). The government even opened some areas to foreign aid

\footnotetext{
${ }^{12}$ Note that Sri Lanka's considerably smaller population than India's does not necessarily indicate that the state is more well governed. For example, while India scored higher in the 2004 World Governance indicators of Voice and Accountability and Government Effectiveness, Sri Lanka scored higher in Political Stability, Regulatory Quality, and Control of Corruption. Indeed, Knack and Azfar (2000) find no relationship between state size and corruption. We adopt a narrow understanding of government capacity here, however, defining it simply as the resources available with which to respond to disasters.
} 
that it had closed off before the disaster struck (Farley 2008). ${ }^{13}$ Reports conclude that Sri Lanka reacted in this manner because "the preexisting civil conflict coupled with the scale of the disaster proved to be too much for the government of Sri Lanka to handle. There simply was not enough capacity on the part of the government to deal with such a massive disaster" (Ching 2011, 6).

\subsubsection{India}

India constitutes one of the world's most disaster-prone countries and possesses limited resources compared to the scale of these crises; thus, prior to 2004, it always accepted offers of aid. ${ }^{14}$ Beginning with the 2004 Indian Ocean tsunami, however, the emerging power has rejected disaster aid to send a costly signal to the international community. ${ }^{15}$ Though India claims that it no longer accepts aid because it no longer needs it, ${ }^{16}$ expert analysis indicates that India does in fact require aid, suggesting that India is a pseudo-competent type of country trying to behave as a truly competent type. For example, after the 2004 tsunami, India's relief efforts were criticized by the disaster relief community as "chaotic" and "pathetic" (Margesson 2005). Five years after the tsunami, the Indian government still had not delivered on many of its aid promises, and many citizens remained without homes (RT News 2010). India failed to respond adequately to subsequent disasters as well (Krishnan 2014) and a recent government audit noted that India's disaster relief agency is "ineffective in its functioning in most of the core areas" (Bhaila 2013). ${ }^{17}$

\footnotetext{
${ }^{13}$ Sri Lanka initially rejected a 150 person rescue mission from Israel due to the military personnel on the crew, but later accepted a delegation of 60 soldiers from Israel instead (Hall 2004). Since this paper focuses on absolute rather than conditional aid rejection, we do not interpret this as a relevant case of aid rejection. ${ }^{14}$ Prominent instances in which India accepted aid include the 2004 Bihar floods, the 2002 Bengal cyclone, the 2001 Gujarat earthquake, the 1993 Latur earthquake, and the 1991 Uttarkashi earthquake (Kasturi 2013).

${ }^{15}$ Though the 2004 Indian Ocean tsunami killed more than 12,000 and displaced over 600,000 in India, the country announced that it would no longer accept disaster aid and provided aid to other states hit by the tsunami instead (Kasturi 2013). Subsequently, following the 2005 Kashmir floods that destroyed 2,500 villages in India and displaced five million people, India accepted no aid but provided aid to Pakistan (Krishnan 2014), and after the 2005 earthquake of magnitude 7.6 killed 1,300 people and displaced 30,000 families, India still refused aid. It also declined aid from the U.S. and Japan after flooding in Uttarakhand killed thousands in 2013 (Kasturi 2013) and from the UN after floods displaced 150,000 in Kashmir in 2014.

${ }^{16}$ An external affairs ministry spokesperson stated, "As a general policy in case of rescue and relief operations, we have followed the practice that we have adequate ability to respond to emergency requirements" (Kasturi 2013). After the 2004 tsunami, Prime Minister Singh stated, "We can cope with the situation on our own" (Kasturi 2013). After the 2005 earthquake, the Indian government insisted it did not need any foreign aid, stating "we ourselves are taking care of our victims" (Sengupta 2005).

${ }^{17}$ An exception to India's policy of aid rejection occurred after it received limited aid following the 2014 Cyclone Hudhud. However, India continued to reject aid afterward, as it did following the 2018 Kerala floods. See Venkataraman, Ayesha, Suhasini Raj and Maria Abi-Habib. "After Worst Kerala Floods in a Century, India Rejects Foreign Aid. New York Times. August 23, 2018. Note that India accepted aid following the Covid-19 outbreak, though the scale of this disaster was largely unprecedented. We also exclude epidemics from our analysis as explained subsequently, so that this episode falls outside the scope of this paper. See Laskar, Rezaul. "Covid-19: India to Accept Help from Abroad for PM-CARES Fund. Hindustan Times. April 1, 2020.
} 
Despite later criticism of India's disaster response effort by experts, the broader international audience appeared to be impressed by India's behavior, particularly because its inadequacies did not become evident until after the media stopped covering the disaster and the public lost interest. For instance, immediately following the 2004 tsunami, the U.S. included India in a "core group" of states that would supply relief to the disaster's victims, reflecting the perception that India had " "graduated' from its long-standing status as an aid recipient to a donor" (Bhaila 2013; Bidwal 2016). In response, many newspapers published articles with headlines such as, "Post-tsunami India's Image Rises Globally" (The Times of India 2005). ${ }^{18}$ Indeed, "many international commentators agreed that India's response to the tsunami highlighted its emergence as a significant power, not only in South Asia but also in the wider global arena" (Harmer et al. 2005, 17).

Policy makers and commentators have connected India's rejection of disaster relief to its "ambitions to assert itself as a world power" (Sengupta 2005). For instance, "foreign diplomats say they are in little doubt that one of New Delhi's key aims in the wake of the tsunami has been to project India as an emerging great power that gives out rather than receives humanitarian aid" (Luce 2005). The director of a private Indian research group said, "We are playing politics with aid, using aid to make a statement" (Sengupta 2005) and The Telegraph claimed that India's aid refusals build "on a quiet but assertive diplomatic aid policy that has coincided with its growing economic clout. It's a policy that has seen India change from a country that happily accepted foreign aid to tide it over natural disasters just a decade ago to a nation that routinely rejects bilateral assistance to handle such crises" (Kasturi 2013).

Similarly, a U.S. official stated, "Frankly, we feel [aid rejection] is a misplaced desire to demonstrate India's self-importance in the region" (Rajghatta 2005) and that "the policy is also about driving home a point to countries that have traditionally led the world's economic system" (Kasturi 2013). A retired Indian diplomat concurred, adding, "There's a certain sense of self-confidence that we can manage it and a desire to signal that you are capable of managing things on your own" (Sengupta 2005). Indeed, the start of India's aid refusal coincided with similar efforts, such as increasing military spending and seeking a permanent seat on the United Nations Security Council. Indian President Mukherjee stated that India was "eminently suited" for the position and had "affirmed its willingness and capacity to shoulder the responsibilities" (Indo-Asian News Service 2012). Backed by high economic growth, which has provided it with the ability to send a credible signal, India appears to have thus deployed an aid rejection strategy to bolster its status.

\footnotetext{
${ }^{18}$ India's aid rejection is unlikely to be driven by domestic considerations. Many Indians deplore its aid rejection since so many of its citizens live in poverty (Harmer et al. 2005, 14). As one summary concluded, "While the government was keen to be perceived as an aid donor internationally, ... India's weak fiscal position and levels of poverty would mean that the transfer of resources to aid other countries' development without any corresponding benefits would be unpopular" (Price 2004, 10).
} 


\section{Survey experiment}

We now investigate our model's predictions more systematically, beginning with our first hypothesis: rejecting aid improves a government's international status unless it is caught concealing incompetence. ${ }^{19}$ Because we are interested in how learning that a country refused aid influences international opinions, we use a survey experiment in which we manipulate this feature of a natural disaster response. In particular, we asked subjects about the 2005 earthquake in India; while all subjects read about the earthquake, only those in the treatment group learned that the government rejected international assistance. ${ }^{20}$ This evidence supports our claims that rejecting aid can be an effective strategy, and we leave tests of how that strategy is used for the crossnational analysis.

As described previously, status results from the consensus of many groups in the international community, and one of those is the mass public. Since the U.S. is the sole superpower, the opinions of its citizens are particularly relevant. Many countries have undertaken costly initiatives to improve their images in the eyes of the U.S. public, underscoring the high value placed on influencing this audience's views. Notable examples include China's and India's cultural tours and centers that have been established in the U.S. and elsewhere, through which the countries seek to exercise soft power. Indeed, India has sought to "improv[e] India's image in American minds" in order to "give legitimacy and credibility to India's leadership role in the world" and such efforts have "now become an active element of India's diplomacy" (Blarel $2012,32) .{ }^{21}$ While we the U.S. mass public is not the only source of international status, it thus constitutes an important one.

Both our treatment and control texts were borrowed from news reports, so individuals were aware that these events actually occurred. All respondents learned about the damage caused by the 2005 earthquake in India. Then, treatment respondents were informed, "India did not ask for outside assistance. The government announced that it did not need international aid to recover." 22

This language best approximates how international observers learn of an aid rejection. The majority of the news articles we reviewed covering dozens of instances of aid rejection use this diplomatic phrasing to describe the event. Potential recipients rarely want to offend the countries offering assistance, so they simply announce that assistance is unnecessary. Since offers of assistance are nearly ubiquitous after disasters, this is tantamount to rejecting aid. If anything, we believe the diplomatic language would weaken the signal of aid rejection, making us less likely to find a treatment effect. We compare our treatment group to a control group, which does

\footnotetext{
${ }^{19}$ While we focus on perceptions in recipient countries, other interesting work examines the determinants of opinions about aid in donor countries. See, e.g Paxton and Knack (2012).

${ }^{20}$ Unless otherwise indicated, we followed the protocol described in our pre-analysis plan, which is available at https://osf.io/bycwk.

${ }^{21}$ For China's efforts, see Rosenthal (2000). Similarly, Pocha (2003, 8-10) notes, "The India government...has been quick to see the importance of its image in the U.S." Further, "New Delhi's objective is clear-to influence other nations, particularly America." In particular, through improving this image it has sought "greater recognition and respect...[and] a more influential place in the modern world."

${ }^{22}$ See the SI for complete text.
} 
not learn anything about whether a country rejected or accepted assistance. While it is possible that some individuals in our control group may also believe that India rejected aid, this would bias against finding any results and therefore again presents a harder test of our claim.

Our dependent variable is the government's reputation or status. The main outcome measure we use is: "Think about how much international status (respect, prestige) you believe India likely has compared with all other countries in the world. Please tell me the number you think best represents India's status relative to the other countries in the world from 1 (the absolute lowest status country in the world) to 100 (the absolute highest status country in the world)." This question is modeled on the most widespread measure of group status in the psychology literature. ${ }^{23}$ To test the mechanism - that rejecting aid increases confidence in a country's self-sufficiencywe asked how confident respondents were that India could handle the disaster using its own resources.

We conducted our experiment through Amazon Mechanical Turk $(\mathrm{N}=756)$ on May 4-9, 2016. While not a representative sample, we have no theoretical reason to expect that our participants would assess information about a foreign country's behavior differently than would average Americans. ${ }^{24}$ Further, MTurk has been shown to replicate studies that rely on nationally representative samples, partly because MTurk participants tend to reply similarly to those of other samples. ${ }^{25}$ Randomization was conducted in Qualtrics through simple random assignment and all of our balance tests, presented in the SI, succeeded. Our manipulation checks indicate that individuals followed and understood the treatment texts: $98 \%$ could identify the type of natural disaster that struck India, and $95 \%$ of our treatment group knew that India did not accept assistance.

Table 1 presents the effects of our treatment on our main outcomes. We observe a statistically significant treatment effect on our primary status indicator. On average, learning of India's decision to reject aid in 2005 improved an individual's assessment of India's status by just over three points on a 100 point scale (about one-sixth of a standard deviation). For comparison, a prominent psychology study using this measure finds a five point difference between individuals that did and did not identify with the group whose status they rated (Pettit and Lount 2010). In other words, the magnitude of our result is substantively meaningful in the individual psychology literature, with aid rejection producing nearly as much of an effect as being an in-group

\footnotetext{
${ }^{23}$ Pettit and Lount (2010) and Pettit et al. (2013) measure university status by asking individuals to "think about how much status (e.g., respect, prestige) you believe University X students have compared to all other university and college students. Please write the number that you think best represents University X's students' status relative to other universities' students from 1 (the absolute lowest status students) to 100 (the absolute highest status students)."

${ }^{24}$ We control for race and country of birth to address the concern that immigrants or diaspora members may hold different international attitudes. Our SI describes our sample.

${ }^{25}$ The correlation between MTurk samples and nationally representative samples of has been shown to be high: .75 according to Mullinix et al. (2015) and .81 according to Coppock (2018). See also Berinsky et al. (2012), Buhrmester et al. (2011), and Mason and Suri (2012).
} 
Table 1 Treatment effects of aid rejection

\begin{tabular}{|c|c|c|c|c|}
\hline & \multicolumn{4}{|c|}{ Dependent variable: } \\
\hline & \multicolumn{2}{|c|}{ Status $(1-100)$} & \multicolumn{2}{|c|}{ Confidence (1-7) } \\
\hline & $(1)$ & (2) & (3) & (4) \\
\hline \multirow[t]{2}{*}{ Reject } & $3.585^{* *}$ & $3.315^{* *}$ & $0.690^{* * *}$ & $0.673^{* * *}$ \\
\hline & $(1.607)$ & $(1.647)$ & $(0.120)$ & $(0.124)$ \\
\hline \multirow[t]{2}{*}{ Age } & & 0.108 & & 0.002 \\
\hline & & $(0.078)$ & & $(0.006)$ \\
\hline \multirow[t]{2}{*}{ Male } & & $9.019^{* * *}$ & & $0.525^{* * *}$ \\
\hline & & $(1.656)$ & & $(0.125)$ \\
\hline \multirow[t]{2}{*}{ Education (1-8) } & & 0.700 & & -0.019 \\
\hline & & $(0.634)$ & & $(0.048)$ \\
\hline \multirow[t]{2}{*}{ Income (1-9) } & & -0.426 & & $-0.077^{* * *}$ \\
\hline & & $(0.357)$ & & $(0.027)$ \\
\hline \multirow[t]{2}{*}{ Republican (1-5) } & & $-1.256^{*}$ & & $0.130^{* *}$ \\
\hline & & $(0.711)$ & & $(0.054)$ \\
\hline \multirow[t]{2}{*}{ News (1-3) } & & 0.242 & & -0.013 \\
\hline & & $(0.993)$ & & $(0.075)$ \\
\hline \multirow[t]{2}{*}{ Follows int'l news $(0-1)$} & & $4.216^{* *}$ & & $0.364^{* * *}$ \\
\hline & & $(1.823)$ & & $(0.137)$ \\
\hline \multirow[t]{2}{*}{ Foreign born $(0-1)$} & & 2.673 & & 0.310 \\
\hline & & $(4.991)$ & & $(0.376)$ \\
\hline Observations & 758 & 754 & 758 & 754 \\
\hline $\mathrm{R}^{2}$ & 0.007 & 0.138 & 0.042 & 0.150 \\
\hline Adjusted $\mathrm{R}^{2}$ & 0.005 & 0.058 & 0.041 & 0.071 \\
\hline
\end{tabular}

${ }^{*} \mathrm{p}<0.1 ;{ }^{* *} \mathrm{p}<0.05 ;{ }^{* * *} \mathrm{p}<0.01$

member. ${ }^{26}$ Countries earn a modest but meaningful status bump when they reject aid, providing the incentive to use this tactic to project images of self-sufficiency. ${ }^{27}$

We also find strong support for the mechanism implied by our theory. The direct effect of our rejection treatment on individuals' confidence in India's ability to handle

\footnotetext{
${ }^{26}$ Benchmarked to the standardized treatment effects reported by other survey experiments in political science, one-sixth is similar, if believably modest. See, e.g. Tomz and Weeks (2020).

${ }^{27} \mathrm{We}$ did not find a statistically significant treatment effect on individuals' ranking of India next to six other countries. Given the size of the treatment effect on status, we believe this measure was not finegrained enough to reveal a statistically significant difference between treatment and control. For similar reasons, we were unable to detect treatment effects on other outcomes we thought could be affected by changes in international status, which were measured on scales of either $1-3$ or $1-7$ and are reported in the SI. However, as shown in Table 3 of the SI, we find that the treatment moves the indicators that our theory would expect—confidence, support, and status—and does not move those that our theory would not expect.
} 
the disaster is about .7 points on a 1-7 scale, and the effect is statistically significant. In the SI, we further model this relationship through mediation analysis, which uses a potential outcomes framework to estimate the effect of rejection on status that is transmitted through confidence in India's capabilities (Imai et al. 2010). The results suggest that fully two-thirds of our total effect may be accounted for by this mechanism. However, we interpret these results with caution as they require minimal correlation between the background causes of confidence and status. ${ }^{28}$

In sum, the findings from our survey experiment support our claims that rejecting aid signals self-sufficiency to international observers whose opinions contribute to a country's international status. Our result is substantively meaningful in the psychological literature on status. While we leave it to future research to demonstrate similar effects on the opinions of other populations or elites, this evidence illustrates that rejecting aid is a plausible way for countries to improve their reputations.

\section{Cross-country analysis}

Our theory also predicts that self-sufficient governments tend to reject assistance following natural disasters because they often have no need for it and wish to avoid the costs associated with accepting aid. Further, since a reputation for self-sufficiency brings a host of benefits, we expect needy governments that place a high value on status to attempt to signal self-sufficiency by similarly rejecting aid. Doing so comes with a cost, though, as the government (1) does not receive the needed aid and (2) risks the detection of its true type by the international community. Because states with fewer resources face steeper costs on both counts, these governments should accept international aid more frequently than governments with more resources, as should states that view higher status as an important goal.

To test these hypotheses systematically, we constructed an original data set comprising 66 natural disasters that occurred between 2004 and 2012. ${ }^{29}$ Our unit of analysis is the natural disaster because this represents the exogenous shock that allows countries to either accept or reject aid. These data come from the EM-DAT International Disaster Database, which records information about the occurrence and

\footnotetext{
${ }^{28}$ Note that our main result disappears when we employ a hypothetical example in which subjects imagine a country facing a disaster rather than its being named as India. This accords with other research suggesting that experimental manipulations employing real-world examples with proper names can produce quite different results than otherwise identical experimental conditions in hypothetical scenarios (Nielson et al. 2019). We believe that this result strengthens our main result because the plausibility of the government's feigned competence is critical to our theory. Unlike India, a hypothetical country might be viewed with much more suspicion. Additionally, our main experimental result disappears when we replicate our results with an Indian sample. We interpret this as evidence that the government in question needs to be plausibly competent in the eyes of subjects. Indians have much more information than Americans and therefore are not fooled by the ploy of rejecting aid. Although we expected a stronger treatment effect among elite (educated) Americans, if anything, we found the reverse, although the result is not statistically significant. See the SI for additional discussion of these findings.

${ }^{29}$ Disasters that occurred in close proximity to each other are considered one disaster for our purposes. For example, when a flood triggers a landslide, we code this as one disaster since aid is offered for both events at once. Further, when a disaster spans two years, we use the year it began in our analysis.
} 
effects of natural disasters, compiling information from UN agencies, NGOs, insurance companies, and research institutions (Guha-Sapir, D., Below, R., Hoyois, P., Accessed 2014. EM-DAT: international disaster database. http://www.emdat.be). We subset our data to the disasters considered most exogenous such as earthquakes, hurricanes, and floods. ${ }^{30}$ Because our interest lies in natural disasters that receive international attention, we select all disasters in which the death toll was at least $300 .^{31}$

For each disaster, we coded (1) whether the affected country chose to categorically reject international assistance, (2) if it rejected international assistance, whether it successfully persuaded the international community that its response, unaided, was sufficient, (3) the extent of the government's resources to respond to the disaster without assistance, and (4) the value the state places on status. We coded our aid rejection variable by drawing upon open source information from news articles and aid agencies. ${ }^{32}$

For each case, we assigned the disaster a binary indicator of whether aid was declined: a disaster received a 1 if the government outright rejected international assistance or tried to refuse international assistance before accepting it. ${ }^{33}$ We selected this definition to capture all cases in which governments attempted to pursue a strategy of rejecting aid. Since we are interested in the government's intent to decline aid, rather than the outcome of the refusal, we include cases as instances of rejection in which the government tried but failed to convince the international community that it could respond adequately to the disaster on its own and resorted to accepting aid. ${ }^{34}$

\footnotetext{
${ }^{30}$ We exclude biological disasters (epidemics) because their timing is highly endogenous to a country's health care system, and climatological natural disasters (extreme temperature, drought, wildfire) because they rarely receive international responses.

${ }^{31}$ This results in a sample that over-represents incompetent governments, since holding the severity of the disaster constant, incompetent governments likely experience higher death tolls than competent ones. However, since these are the governments for which our model produces the most interesting theoretical predictions, this is less of a concern. We do show in the SI that our results are robust to sample specifications of 400, 500, and 600 deaths.

${ }^{32} \mathrm{~A}$ write-up of each disaster and a justification of each coding decision is available in the SI.

${ }^{33}$ We do not use quantitative disaster aid data because we are unable to distinguish between the amount of aid offered and the amount of aid accepted. However, we include these figures in our case study descriptions and use them along with other available sources to code cases and test the strategic logic of our argument.

${ }^{34}$ Only five governments that rejected aid-Bangladesh 2004, Chile 2010, Indonesia 2010, Pakistan 2011, and Pakistan 2012 - ultimately ended up accepting it, and in each case the government initially pursued the rejection strategy seriously. A month after flooding began in Bangladesh, for example, the BBC reported, "The government is still refusing to call for international help saying its own relief efforts are enough, but several large NGOs have said it should now reconsider" (BBC 2004). Oxfam, Save the Children, and Care International issued a report accusing Pakistan in 2011 of not permitting international aid agencies to assist, and "consequently, precious time was lost and opportunities were missed to minimise the impact of the flood" (The Telegraph 2012). Similarly in 2012, the National Disaster Management Authority of Pakistan announced, "The government's point of view is that the situation will be handled from own resources" a month into the crisis (BBC 2012). In Chile, the government linked Chile's reputation as a "very strong government" with strong institutions to its ability to handle rescue and relief on its own when it touted that Chile was the best disaster-prepared country in Latin America (United Nations 2010). These efforts, while ultimately aborted, constituted genuine attempts to pursue a rejection strategy in the immediate aftermath of a disaster.
} 
We do not count as instances of rejection cases in which a state declined aid from a single country, as this type of behavior typically arises from interstate hostilities rather than the dynamics we identify. Further, rejecting aid in this manner often carries diplomatic costs, unlike blanket rejections which typically do not, as evidenced in our case study research. If states were to reject just some offers of aid while accepting others, this would not send the self-sufficiency signal essential to our theory, which is why we code only categorical aid rejection.

We also used our qualitative research to code the degree of success with which governments rejected aid. Many cases exist in which the government declined aid at first, but the international community quickly discerned that it could not respond adequately on its own. We code whether governments pursuing aid rejection strategies faced international criticism for doing so: were these governments openly criticized by other governments, international organizations, and aid agencies for poor responses and for rejecting international assistance? We coded the country as 1 if its response did not attract international criticism, and 0 if it was openly condemned. By coding this qualitatively, our measure reflects the media's view because this is our quantity of interest; we want to know whether governments were "caught" by the international community.

Additionally, we created a measure of how capable the government was of responding to the disaster using its own resources by dividing the country's GDP by the number of people killed in the disaster. ${ }^{35}$ A higher ratio indicates greater capabilities. We chose this measure over a more qualitative coding to avoid a measure that is a function of the strategy the government selects. However, as a robustness check, we also use logged GDP in an alternative specification.

Further, we code whether states care about status using a measure of their logged military expenditures. Since many scholars have shown that bigger militaries accord higher status to a country, military investments signify that states value that status and are undertaking costly efforts to obtain it. ${ }^{36}$ However, since military expenditures can proxy for non-status dynamics (such as the threats faced by a regime), we also employ an alternative measure - an indicator of whether a given state possesses or seeks a permanent seat on the United Nations Security Council-as a robustness check. ${ }^{37}$ Since certain regime types may be less receptive to assistance, we include control variables such as GDP growth, respect for human rights, democracy, and

\footnotetext{
${ }^{35}$ GDP data come from the World Bank World Development Indicators and the data on the number killed come from EM-DAT. Data on GDP is unavailable for three cases: North Korea, Myanmar, and Taiwan. In each of these cases, however, the government was clearly incapable of responding to the disaster using its own resources, so we code them as such.

${ }^{36}$ For works using military size to proxy for status, see e.g., Vayrynen (1971), Deger and Smith (1983), Kammler (1997), and Volgy et al. (2011). Defense spending is often attributed to a desire for status both in the press and in scholarly work. See, e.g. The Economist (2014) and Harris (2002). Indeed, scholars typically rely on military expenditure to proxy for status-seeking behaviors. See, e.g., Singer (1988) and Duque (2018).

${ }^{37}$ Malone (2000) summarizes, "The dominant view at the UN is that countries aim for membership in the council to underscore their international prestige." Stolte (2015) illustrates the importance of status aspirations to Brazil's bid for a UNSC permanent seat, which is "the ultimate symbol of international recognition as a Great Power."
} 
other logged foreign aid; we also control for whether the disaster was an earthquake, since these disasters are especially salient in the news. ${ }^{38}$

Figure 1 provides a visual representation of the relationships between our key variables. In panel (a), we plot our cases according to each government's logged ability to respond to a given disaster. Red points indicate countries that accepted aid, while green and blue points depict those that rejected aid. The figure shows that cases in which a country possessed a fewer resources tend to be red, while there exist very few red points at high levels of capacity. ${ }^{39}$ This supports our claim that governments that are most incapable of responding to disasters (e.g. Haiti, Bangladesh, Philippines) choose to accept assistance because they cannot succeed in fooling the international community. In panel (b), we plot our cases according to a government's value of status. The figure shows that, in accordance with our theory, all but one instances of aid rejection lie above the $1 \%$ line, as states that place higher importance on status tend to decline aid. It is worth noting that the states that rejected aid are typically either high status or ambitious middle-income countries. For high status countries (e.g., U.S., China, and Japan), accepting aid would be embarrassing. ${ }^{40}$ For middle-income countries with ambitious aspirations (e.g. Thailand, Turkey, India, and Iran), rejecting foreign aid is hoped to change the international community's impression of their self-sufficiency.

Having examined our data visually, we turn to a statistical analysis. ${ }^{41}$ Since our outcome variable is binary, we run a logistic regression, with robust standard errors clustered by country. In Model 1 of Table 2, we present basic correlations, regressing the indicator variable for aid rejection on our measure of the government's ability to respond to the disaster and its concern for status. To account for characteristics common to particular regions, Model 2 displays the results of the same regression, but adds region and year fixed effects. To check the sensitivity of our results to modeling assumptions, Model 3 uses OLS instead of logit. Models 4 and 5 use alternative measures of our key independent variables-logged GDP represents a government's need for assistance in model 4 and an indicator of whether a country currently possesses or has seriously sought a permanent seat on the UNSC indicates that the government values status in model 5. Model 6 then adds covariates. In particular, we control for the acceptance of other aid to address the possibility that our measure of a state's capacity to respond captures characteristics that predispose states to accept or reject aid. We also control for democracy and human rights to mitigate concerns about the types of governments that have high military expenditures. ${ }^{42}$ Across nearly all

\footnotetext{
${ }^{38}$ Human rights data are taken from Cingranelli and Pasquarello (1985), democracy data come from Marshall and Jaggers (2002), foreign aid and military expenditure data are from the World Development Indicators (2012), and data on disaster type come from EM-DAT.

${ }^{39}$ Two outliers occurred in China (both in 2006) but we note that China did not request international assistance in either; it only accepted it.

${ }^{40}$ Note that in panel (a), Japan's ability to respond in 2011 falls within the range of the Philippines's ability to respond, implying that it could have made use of foreign aid and nonetheless chose not to.

${ }^{41}$ Our sample size decreases slightly due to missing GDP data for some of our country-years.

${ }^{42}$ Results presented in the SI demonstrate the robustness of our findings to the use of lagged military expenditures.
} 


\section{(a) By ability to respond}

\section{- Accepted - Rejected, and succeeded - Rejected, but failed}

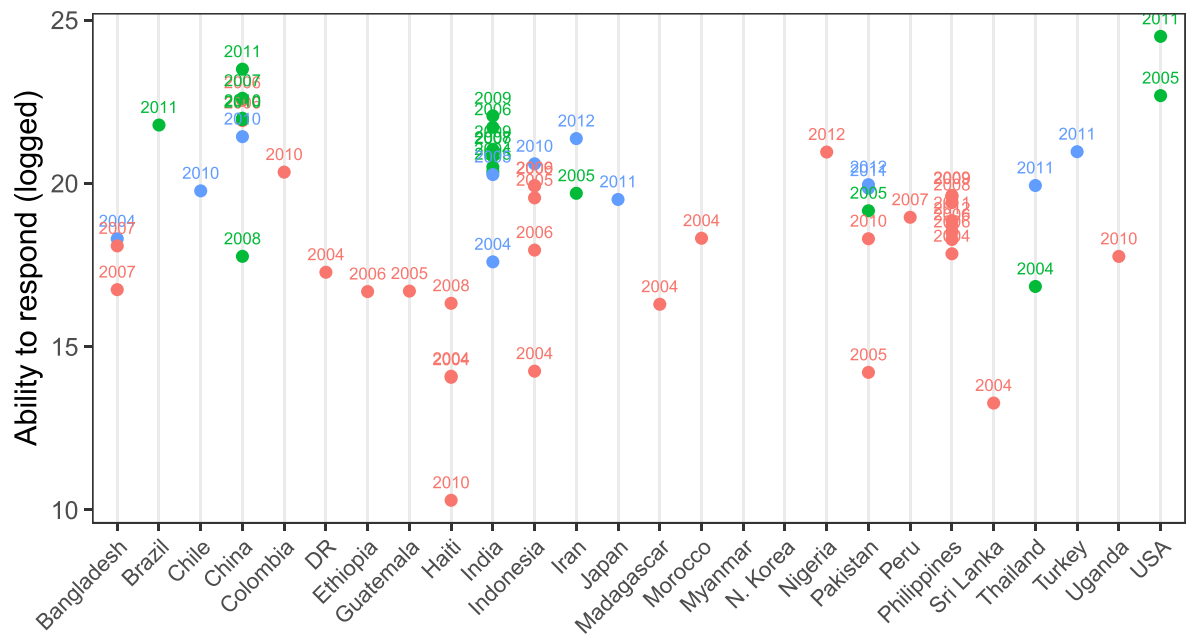

(b) By concern for status

\section{- Accepted Rejected, and succeeded - Rejected, but failed}

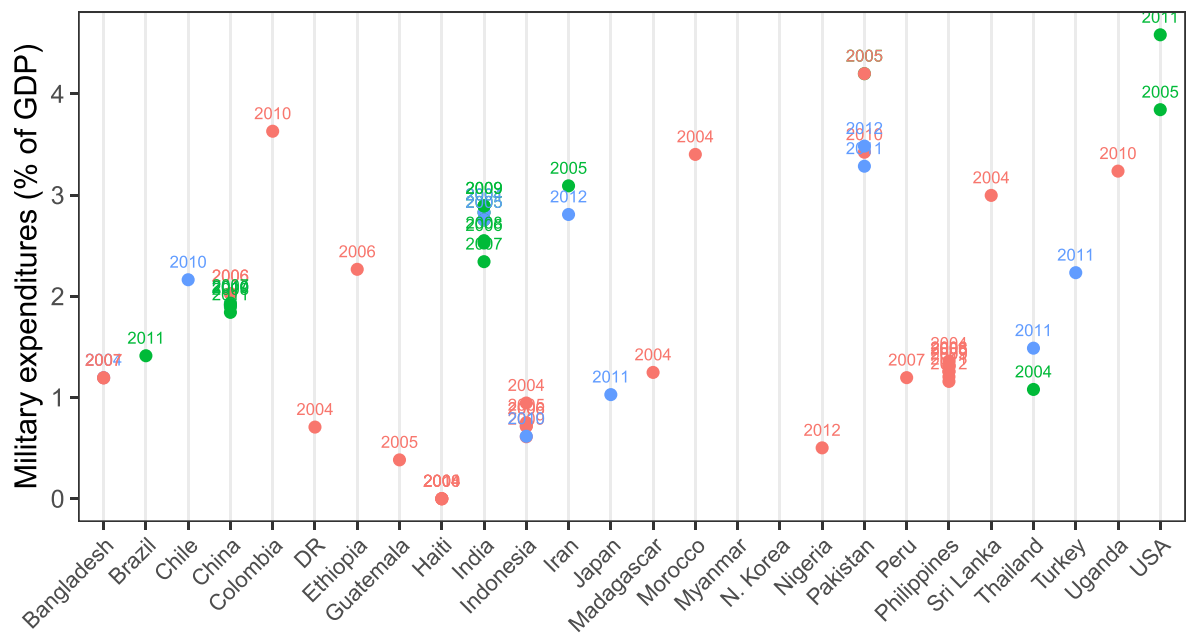

Fig. 1 Aidesponses in 66 natural disasters, 2004-2012. Note: GDP data is missing for North Korea '07 (acceptance), Myanmar '08 (unsuccessful rejection), and Taiwan '09 (unsuccessful rejection), so we are unable to quantitatively calculate the ability to respond ratio. Our qualitative research shows that all three states had low abilities to respond 
Table 2 Statistical analysis of 66 natural disasters, 2004-2012

\begin{tabular}{|c|c|c|c|c|c|c|}
\hline & \multicolumn{6}{|c|}{ Accepted aid $(0-1)$} \\
\hline & (1) & (2) & (3) & (4) & (5) & (6) \\
\hline Ability to respond & $\begin{array}{l}-0.667^{\text {**** }} \\
(0.221)\end{array}$ & $\begin{array}{l}-1.587^{\text {*** }} \\
(0.373)\end{array}$ & $\begin{array}{l}-0.096^{* * *} \\
(0.026)\end{array}$ & & $\begin{array}{l}-1.531^{* * *} \\
(0.449)\end{array}$ & $\begin{array}{l}-1.809^{* * *} \\
(0.582)\end{array}$ \\
\hline Log GDP & & & & $\begin{array}{l}-2.037^{\text {*** }} \\
(0.449)\end{array}$ & & \\
\hline Military expenditures & $\begin{array}{l}-0.773^{* *} \\
(0.369)\end{array}$ & $\begin{array}{l}-1.082^{\text {*** }} \\
(0.392)\end{array}$ & $\begin{array}{l}-0.087 \\
(0.058)\end{array}$ & $\begin{array}{l}-0.975^{\text {*** }} \\
(0.312)\end{array}$ & & $\begin{array}{l}-2.058^{* *} \\
(0.833)\end{array}$ \\
\hline UNSC & & & & & $\begin{array}{l}-17.832^{* * *} \\
(1.302)\end{array}$ & \\
\hline Log other aid & & & & & & $\begin{array}{l}-0.264 \\
(0.736)\end{array}$ \\
\hline Human rights & & & & & & $\begin{array}{l}2.611^{* *} \\
(1.217)\end{array}$ \\
\hline Democracy & & & & & & $\begin{array}{l}0.449^{* *} \\
(0.209)\end{array}$ \\
\hline Model & Logit & Logit & OLS & Logit & Logit & Logit \\
\hline Year F.E.s? & No & Yes & Yes & Yes & Yes & Yes \\
\hline Region F.E.s? & No & Yes & Yes & Yes & Yes & Yes \\
\hline Observations & 63 & 63 & 63 & 63 & 63 & 56 \\
\hline
\end{tabular}

${ }^{*} \mathrm{p}<0.1 ;{ }^{* *} \mathrm{p}<0.05 ;{ }^{* * *} \mathrm{p}<0.01$

specifications, both the ability to respond to a disaster and the desire for status are significant predictors of whether a government accepts aid. ${ }^{43}$

We also perform additional robustness checks, which appear in the SI due to space constraints. While our analysis focuses on the as-if random timing of disasters, we acknowledge that disaster damage is endogeneous. To mitigate these concerns, we demonstrate that our results are not sensitive to the particular sample of disasters used. ${ }^{44}$ First, we limit our sample to earthquakes and include those with a high magnitude on the Richter Scale in which the shaking affected a population center. Second, we analyze our original data using alternative thresholds for how many people died in the disaster to warrant the disaster's inclusion in the sample. Our results are robust to both exercises.

\footnotetext{
${ }^{43}$ Only in Model 3 (OLS), does military expenditure lose significance at conventional levels ( $\left.\mathrm{p}=.14\right)$.

${ }^{44}$ We prefer this approach to the inclusion of country fixed effects in such a small sample, as 15 of our 66 disasters are in countries with just one disaster, and which therefore exhibit no over-time variation. However, our main model is robust to substituting region for country fixed effects with unclustered standard errors.
} 


\section{Alternative explanations}

We consider several alternative explanations for why countries could reject international assistance after a natural disaster. First, perhaps governments sometimes lack the bureaucratic capacity to receive international assistance. They might therefore decline aid simply because they cannot absorb it. However, this explanation is not likely driving our results, and actually may work against them. Countries with limited bureaucratic capacity tend to possess fewer resources in general. Thus, if this argument held up, countries with lower capacity should be more likely to reject aidthe opposite of what we observe. Further, in coding our cases, we did not encounter evidence that governments with difficulties absorbing aid rejected the aid as a result. Instead, aid was still provided but the disbursement was slow and inefficient. ${ }^{45}$ Finally, in our main results, we control for a government's receipt of other aid. Thus, while governments do sometimes experience difficulties managing aid flows, these problems cannot account for our findings.

Another alternative theory is that states reject disaster assistance because they want to keep international influence out of their countries. ${ }^{46}$ Yet here too, we find little evidence in favor of this explanation. Like the previous alternative story, if this were true, it would cut against our findings. Countries that shun foreigners tend to be small and resource poor. These kinds of countries may violate international norms and seek to hide their activities, or are unstable and do not want international intervention. ${ }^{47}$ Thus, if this explanation held, we would expect states with fewer resources to reject aid, while we instead see that states with greater resources tend to do so.

In our qualitative research, we also encountered very few instances that would support this logic. One country that did seem to reject assistance for this reason was Myanmar, which considered refusing aid after a cyclone devastated the country in 2008 in part because it feared foreign influence. In particular, the regime worried that accepting aid could increase the risk of an invasion (Selth 2008). Due to threats and pressure from the international community, Myanmar eventually accepted limited aid, but still demanded that it control its distribution (Farley 2008). The case of Myanmar shows that some truly extreme cases remain anomalies in our data. However, such cases are rare; other closed regimes - such as Sri Lanka and North Korea-opened their doors when disasters struck. ${ }^{48}$ Even so, we account for the possibility that states shun assistance due to worries that their human rights violations will be detected by including respect for human rights as a control variable in our main specification.

Finally, perhaps some governments reject aid to signal competence to their domestic populations. However, we find this explanation to be unpersuasive for several reasons. Theoretically, previous work has shown that citizens impacted by natural

\footnotetext{
${ }^{45}$ This occurred, for example, in the 2010 Haitian earthquake (Breaking News 2010).

${ }^{46}$ For example, see Dupuy et al. (2016). For more on countries' sensitive information see Carnegie and Carson (2020).

${ }^{47}$ On the connection between such instability and economic stagnation see Keefer and Knack (1998). On violations of norms see Carnegie and Carson (2019).

${ }^{48}$ Our coding of all cases is available in the SI.
} 
disasters demonstrate increased interest in politics and punish politicians at the polls unless they receive relief (Fair et al. 2017; Sinclair et al. 2011). Since disaster aid also presents opportunities for patronage and clientelism, and domestic audiences are likely difficult to fool because they experience the government's performance firsthand, turning down this assistance should carry high domestic costs (Achen and Bartels 2004).

Empirically, we saw many instances in which governments were punished domestically for rejecting aid in the qualitative coding of our cases, and few where doing so provided a domestic benefit. Even in cases in which the government experienced a domestic boost from doing so-as occurred after several disasters in China-the government chose to reject aid mainly due to international considerations. Further, we ran our survey on a sample of Indian citizens, and found no evidence that the same aid rejection treatment that improved Americans' opinions of India held any sway among Indians themselves. ${ }^{49}$ These findings suggest an international-rather than a domestic-motivation for rejecting aid.

\section{Conclusion}

We show that some governments attempt to reject offers of foreign assistance in order to improve their status in the international community. Whereas accepting foreign aid signals that a government requires external resources to deal with an unforeseen and costly event, rejecting foreign aid demonstrates self-sufficiency and accrues international respect, as shown through our survey experiment. Our formal model predicts that governments are more likely to use rejection strategies when they have greater ability to respond to a disaster and when they value status more highly. The results from our original survey experiment and analysis of new data comport with our theoretical predictions.

Though we focus on the domain of disaster aid, our theory applies to many other empirical areas such as development aid, loans, peacekeeping, and military assistance, as well as other kinds of shocks, such as economic and refugee crises. These remain fruitful directions for future research. More generally, other steps that states can take to limit their receipt of international assistance short of refusal could be productively examined; for example, scholars could study graduation from aid programs (Carnegie and Samii 2019) or upward revisions of income calculations that render states ineligible for foreign aid. These seemingly irrational actions could also elicit greater status by demonstrating self-sufficiency. Further, how and when states adopt methods such as aid rejection instead of engaging in wars to improve status or due to other geopolitical considerations ${ }^{50}$ remains an interesting avenue for scholars to explore.

\footnotetext{
${ }^{49}$ Results from this survey are available in the SI. It is possible that these null results reflect Indian's greater knowledge of the government's competence; yet, that again would suggest that the government does not reject aid to signal competence to the domestic population.

${ }^{50}$ Carnegie and Gaikwad (2017).
} 
Our study also suggests several policy implications. First, our findings imply that while states often heavily publicize their efforts to assist other states in order to reap the prestige and positive image associated with these activities, a more effective way to help may be to do so quietly. If assistance is not widely known, states face a smaller hit to their status when accepting it. Second, since we have demonstrated that states so strongly seek improved status that they often take actions detrimental to their economic well-being, it is possible that offering such avenues could effectively motivate states to make concessions in exchange, perhaps in areas such as human rights or democracy. Finally, since we have likely identified one of many avenues short of war through which states can improve their status, encouraging states to pursue such strategies or making them increasingly available could potentially help to avoid costly future conflicts.

\section{References}

Achen, C., \& Bartels, L. (2004). Blind retrospection: electoral responses to drought, flu, and shark attacks. Estudios/Working Papers (Centro de Estudios Avanzados en Ciencias Sociales) (199):1. http:// www.ib.ethz.ch/content/dam/ethz/special-interest/gess/cis/international-relations-dam/Teaching/ pwgrundlagenopenaccess/Weitere/AchenBartels.pdf.

Adler-Nissen, R. (2014). Stigma management in international relations: transgressive identities, norms and order in international society. International Organization, 68(1), 143-176.

Ahmed, F. (2012). The perils of unearned foreign income: aid, remittances, and government survival. American Political Science Review, 106(01), 146-165.

Akcinaroglu, S., DiCicco, J., Radziszewski, E. (2011). Avalanches and olive branches: a multimethod analysis of disasters and peacemaking in interstate rivalries. Political Research Quarterly, 64, 260275 .

Bates, R., \& Lien, D. (1985). A note on taxation, development, and representative government. Politics \& Society, 14, 53-70.

BBC (2004). Bangladesh flood crisis worsens. $B B C$.

BBC (2012). Pakistan floods 'kill more than 400' over past fortnight. $B B C$.

BBC News (2015). Kenya's Uhuru Kenyatta Urges Africa to give up aid. BBC News.

Beardsley, K., \& McQuinn, B. (2009). Rebel groups as predatory organizations the political effects of the 2004 Tsunami in Indonesia and Sri Lanka. Journal of Conflict Resolution, 53(4), 624-645.

Berinsky, A., Huber, G., Lenz, G. (2012). Evaluating online labor markets for experimental research: Amazon com's Mechanical Turk. Political Analysis, 20(3), 351-368.

Bermeo, S.B. (2016). Aid is not oil: donor preferences, heterogeneous aid, and the aid-democratization relationship. International Organization, 70(1), 1-32.

Besley, T., \& Burgess, R. (2002). The political economy of government responsiveness: theory and evidence from India. Quarterly Journal of Economics, 117, 1415-1451.

Bhaila, N. (2013). India Disaster relief agency not ready for calamities-audit. Thomson Reuters Foundation.

Bidwal, P. (2016). Tsunami impact: loss of innocence in the politics of aid. Inter Press Service.

Blarel, N. (2012). India's soft power: from potential to reality?. India: The Next Superpower, pp. $28-33$. https://eprints.1se.ac.uk/43445/.

Brass, J. (2016). Allies or adversaries? NGOs and the State in Africa. Cambridge: Cambridge University Press.

Bräutigam, D.A., \& Knack, S. (2004). Foreign aid, institutions, and governance in sub-Saharan Africa. Economic Development and Cultural Change, 52(2), 255-285.

Breaking News (2010). Desperation as bureaucracy slows aid effort in Haiti. Breaking News.

Buhrmester, M., Kwang, T., Gosling, S. (2011). Amazon's mechanical Turk a new source of inexpensive, yet high-quality, data? Perspectives on Psychological Science, 6(1), 3-5. 
Carnegie, A., \& Carson, A. (2019). Reckless rhetoric? Compliance pessimism and international order in the age of Trump. The Journal of Politics, 81(2), 739-746.

Carnegie, A., \& Carson, A. (2020). Secrets in global governance: disclosure dilemmas and the challenge of international cooperation (Vol. 154). Cambridge: Cambridge University Press.

Carnegie, A., \& Gaikwad, N. (2017). Public opinion on geopolitics and trade: Theory and evidence. Available at SSRN 2909761.

Carnegie, A., \& Samii, C. (2019). International institutions and political liberalization: evidence from the World Bank loans program. British Journal of Political Science, 49(4), 1357-1379.

Carothers, T. (2006). The backlash against democracy promotion. Foreign Affairs, 85(2), 55-68.

Ching, E. (2011). Best practices and lessons learned: the humanitarian response in Post-Tsunami Sri Lanka. https://www.du.edu/korbel/crric/media/documents/erinching.pdf.

Cingranelli, D., \& Pasquarello, T. (1985). Human rights practices and the distribution of US foreign aid to Latin American Countries. American Journal of Political Science, 29(3), 539-563.

Cole, S., Healy, A., Werker, E. (2012). Do voters demand responsive governments? Evidence from Indian disaster relief. Journal of Development Economics, 97(2), 167-181.

Coppock, A. (2018). Generalizing from survey experiments conducted on mechanical Turk: a replication approach. Political Science Research and Methods, 7(3), 613-628.

Crawford, G., et al. (2001). Foreign aid and political reform: a comparative analysis of democracy assistance and political conditionality. New York: Palgrave Publishers Ltd.

Dafoe, A., Renshon, J., Huth, P. (2014). Reputation and status as motives for war. Annual Review of Political Science, 17, 371-393.

Davis, C.L. (2016). More than just a rich country club: membership conditionality and institutional reform in the OECD.

De La Cuesta, B., Milner, H.V., Nielson, D., Knack, S. (2017). Taxation without representation? Experimental evidence from Ghana and Uganda on citizen action toward taxes, oil, and aid. Washington, D.C.: The World Bank.

De Mesquita, B.B., \& Smith, A. (2009). A political economy of aid. International Organization, 63(2), 309-340.

De Mesquita, B.B., \& Smith, A. (2013). Aid: blame it all on easy money. Journal of Conflict Resolution, 57(3), 524-537.

Deger, S., \& Smith, R. (1983). Military expenditure and growth in less developed countries. Journal of Conflict Resolution, 27(2), 335-353.

Dietrich, S., Mahmud, M., Winters, M. (2018). Foreign aid, foreign policy, and domestic government legitimacy: survey experimental evidence from Bangladesh. Journal of Politics, 80(1), 133-148.

Djankov, S., Montalvo, J.G., Reynal-Querol, M. (2008). The curse of aid. Journal of Economic Growth, 13(3), 169-194.

Djerf-Pierre, M. (2013). Green metacycles of attention: reassessing the attention cycles of environmental news reporting 1961-2010. Public Understanding of Science, 22(4), 495-512.

Dolan, L. et al. (2020). Rethinking foreign aid and government legitimacy: Evidence from aid recipients in Kenya. Studies in Comparative International Development, 55(2), 143-159.

Dupuy, K., Ron, J., Prakash, A. (2016). Hands off my regime! Governments' restrictions on foreign aid to non-governmental organizations in poor and middle-income countries. World Development, 84, 299311.

Duque, M.G. (2018). Recognizing international status: a relational approach. International Studies Quarterly, 62(3), 577-592.

Eisensee, T., \& Strömberg, D. (2007). News droughts, news floods, and US disaster relief. The Quarterly Journal of Economics, 122(2), 693-728.

Fair, C., Kuhn, P., Malhotra, N., Shapiro, J. (2017). Natural disasters and political engagement: evidence from the 2010-11 Pakistani floods. Quarterly Journal of Political Science, 12, 99-141.

Farley, M. (2008). How to help when help is refused? The Los Angeles Times.

Gilligan, A. (2012). India tells Britain: we don't want your aid. The Telegraph.

Gray, J. (2013). The company states keep: international economic organizations and investor perceptions. Cambridge: Cambridge University Press.

Hafner-Burton, E., \& Montgomery, A. (2006). Power positions: international organizations, social networks, and conflict. Journal of Conflict Resolution, 50(1), 3-27.

Hall, R. (2004). Sri Lanka, India Reject Aid for Disaster Victims. CNS News. 
Harmer, A., Cotterrell, L., London Overseas Development Institute (2005). Diversity in donorship: the changing landscape of official humanitarian aid. Humanitarian Policy Group, Overseas Development Institute. https://www.odi.org/projects/338-diversity-donorship-changing-landscape-officialhumanitarian-aid.

Harris, G. (2002). Military expenditure and economic development in Asia during the 1990s. In Arming the South (pp. 71-98): Palgrave MacMillan.

Healy, A., \& Malhotra, N. (2009). Myopic voters and natural disaster policy. American Political Science Review, 103(03), 387-406.

Heffetz, O., \& Frank, R. (2008). Preferences for status: evidence and economic implications. Handbook of Social Economics, 1, 69-91.

Hyde, S. (2011). Catch us if you can: election monitoring and international norm diffusion. American Journal of Political Science, 55(2), 356-369.

Imai, K., Keele, L., Tingley, D. (2010). A general approach to causal mediation analysis. Psychological Methods, 15(4), 309.

Indo-Asian News Service (2012). India eminently suited for permanent UN security council seat: President. Indo-Asian News Service.

Jerven, M. (2013). Poor numbers: how we are misled by African development statistics and what to do about it. Ithaca: Cornell University Press.

Kammler, H.ans. (1997). Not for security only: the demand for international status and defence expenditure. Defence and Peace Economics, 8(1), 1-16.

Kasturi, C. S. (2013). Foreign aid? No, thanks. The Telegraph.

Keefer, P., \& Knack, S. (1998). Political stability and economic stagnation. In The political dimension of economic growth (pp. 136-153). Berlin: Springer.

Kelman, I. (2011). Disaster diplomacy: how disasters affect peace and conflict. London: Routledge.

Knack, S. (2001). Aid dependence and the quality of governance: a cross-country empirical analysis. Southern Economic Journal, 68(2), 310-329.

Knack, S. (2004). Does foreign aid promote democracy? International Studies Quarterly, 48(1), 251-266.

Knack, S. (2013). Aid and donor trust in recipient country systems. Journal of Development Economics, 101, 316-329.

Knack, S.F., \& Azfar, O. (2000). Are larger countries really more corrupt? (Vol. 2470). World Bank.

Knack, S., Putnam, T.R., et al (2000). Social capital and the quality of government.

Krishnan, M. (2014). Disaster management: India's big challenge. Deutsche Welle.

Kuusik, R. (2006). Estonia's development cooperation: power, prestige and practice of a new donor. The Estonian Foreign Policy Yearbook 2006.

Lancaster, C. (1999). Aid to Africa: so much to do, so little done. Chicago: University of Chicago Press.

Levi, M. (1998). A state of trust. Trust and Governance, 1, 77-101.

Levite, A. (2003). Never say never again: nuclear reversal revisited. International Security, 27(3), 59-88.

Luce, E. (2005). India defends refusal to accept foreign aid. Financial Times.

Malone, D. (2000). Eyes on the prize: the quest for nonpermanent seats on the UN Security Council. Global Governance, 6(1), 3-23.

Margesson, R. (2005). Indian Ocean Earthquake and Tsunami: humanitarian assistance and relief operations. DTIC Document. http://congressionalresearch.com/RL32715/document.php.

Marshall, M., \& Jaggers, K. (2002). Polity IV dataset. Computer file.

Mason, W., \& Suri, S. (2012). Conducting behavioral research on Amazon's mechanical Turk. Behavior Research Methods, 44(1), 1-23.

Milner, H., Nielson, D., Findley, M. (2013). Which devil in development? A randomized study of citizen actions supporting foreign aid in Uganda. Social Science Research Network Working Paper. https:// papers.ssrn.com/sol3/papers.cfm?abstract_id=2134409.

Morrison, K. (2014). Nontaxation and representation. Cambridge: Cambridge University Press.

Mullinix, K., Leeper, T., Druckman, J., Freese, J. (2015). The generalizability of survey experiments. Journal of Experimental Political Science, 2(02), 109-138.

Nelson, T. (2010). Rejecting the gift horse: international politics of disaster aid refusal. Conflict, Security \& Development, 10(3), 379-402.

Nielson, D.L., Hyde, S.D., Kelley, J. (2019). The elusive sources of legitimacy beliefs: civil society views of international election observers. The Review of International Organizations, 14(4), 685-715.

Pakistan Today (2011). Punjab Govt. vows to reject foreign aid, boost trade. Pakistan Today. 
Paler, L. (2013). Keeping the public purse: an experiment in windfalls, taxes, and the incentives to restrain government. American Political Science Review, 107(4), 706-725.

Paxton, P.amela., \& Knack, S.tephen. (2012). Individual and country-level factors affecting support for foreign aid. International Political Science Review, 33(2), 171-192.

Pettit, N., \& Lount, R. (2010). Through whose eyes? The impact of identification on judgments of group status. Group Processes \& Intergroup Relations 533-547.

Pettit, N., Sivanathan, N., Gladstone, E., Marr, J.C. (2013). Rising stars and sinking ships consequences of status momentum. Psychological Science, 24(8), 1579-1584.

Pinker, S., Nowak, M., Lee, J. (2008). The logic of indirect speech. Proceedings of the National Academy of Sciences, 105(3), 833-838.

Pocha, J. (2003). The rising soft power of India and China. New Perspectives Quarterly, 20(1), 4-13.

Price, G. (2004). India's aid dynamics: from recipient to donor. Asia Programme Working PapersChatham House. https://www.chathamhouse.org/sites/default/files/public/Research/Asia/wp200904. pdf.

Rajghatta, C. (2005). India's Tsunami aid phobia misplaced? The Times of India.

Renshon, J. (2016). Status deficits and war. International Organization, 70(3), 513-550.

Rosenthal, E. (2000). China's U.S. road show, aimed at making friends. The New York Times.

RT News (2010). Tsunami Victims in India still Waiting for Compensation. RT News.

Sacks, A. (2012). Can donors and non-state actors undermine citizens' legitimating beliefs? World Bank Policy Research Working Paper 6158. https://siteresources.worldbank.org/EXTPREMNET/ Resources/EP95.pdf.

Selth, A. (2008). Even paranoids have enemies: cyclone Nargis and Myanmar's fears of invasion. Contemporary Southeast Asia: A Journal of International and Strategic Affairs, 30(3), 379-402.

Sengupta, S. (2005). Pride and politics: India rejects quake aid. The New York Times.

Sinclair, B., Hall, T., Alvarez, M. (2011). Flooding the vote: hurricane Katrina and voter participation in New Orleans. American Politics Research, 39(5), 921-957.

Singer, D. (1988). Reconstructing the correlates of war dataset on material capabilities of States, 18161985. International Interactions, 14(2), 115-132.

Stolte, C. (2015). Brazil's Africa strategy: role conception and the drive for international status. Berlin: Springer.

The Economist (2014). Arms and the African. The Economist.

The Guardian (2014). Where did the Indian Ocean Tsunami aid money go? The Guardian.

The Telegraph (2012). Two million at risk but Pakistan 'refused to allow aid agencies to help after floods. The Telegraph.

The Times of India (2005). Post-tsunami India's image rises globally. The Times of India.

Tomz, M. (2012). Reputation and international cooperation: sovereign debt across three centuries. Princeton: Princeton University Press.

Tomz, M., \& Weeks, J. (2020). Human rights and public support for war. Journal of Politics, 82(1), $182-194$.

Towns, A. (2010). Women and states: norms and hierarchies in international society. Cambridge: Cambridge University Press.

United Nations (2010). Press conference on Chile by deputy emergency relief coordinator. United Nations.

Vayrynen, R. (1971). On the definition and measurement of small power status. Cooperation and Conflict, 6(1), 91-102.

Volgy, T., Corbetta, R., Grant, K., Baird, R. (2011). Major powers and the quest for status in international politics: global and regional perspectives. Berlin: Springer.

Winters, M.S., \& Streitfeld, J.D. (2011). Splitting the check: counterpart commitments in World Bank projects. World Bank.

Wohlforth, W.C. (2009). Unipolarity, status competition, and great power war. World Politics, 61(01), 2857.

Yamada, S., Gunatilake, R., Roytman, T., Gunatilake, S., Fernando, T., Fernando, L. (2006). The Sri Lanka Tsunami experience. Disaster Management \& Response, 4(2), 38-48.

Publisher's note Springer Nature remains neutral with regard to jurisdictional claims in published maps and institutional affiliations. 